\title{
Infliximab treatment in pathology-confirmed neurosarcoidosis
}

\author{
Daan Fritz, MD, * Wilhelmina M.C. Timmermans, MD, * Jan A.M. van Laar, MD, PhD, \\ P. Martin van Hagen, MD, PhD, Theodora A.M. Siepman, MD, Diederik van de Beek, MD, PhD, and \\ Matthijs C. Brouwer, MD, PhD
}

Neurol Neuroimmunol Neuroinflamm 2020;7:e847. doi:10.1212/NXI.0000000000000847

\author{
Correspondence \\ Dr. Brouwer \\ m.c.brouwer@amc.uva.nl
}

\section{MORE ONLINE}

\section{$\rightarrow$ Class of Evidence}

Criteria for rating

therapeutic and diagnostic

studies

NPub.org/coe

\section{Methods}

In a retrospective study in 2 tertiary referral centers in the Netherlands, we analyzed clinical characteristics, complications, and outcome of patients with neurosarcoidosis treated with infliximab.

\section{Results}

Twenty-eight patients were identified with a mean age of 42 years. Neurosarcoidosis presented with a cerebral parenchymal localization in $16(59 \%)$, pituitary gland/hypothalamic sarcoidosis in $15(54 \%)$, peripheral nerve involvement in 12 (43\%), and chronic meningitis in 11 patients $(41 \%)$. Initial treatment response after the start of infliximab was complete remission in 6 $(21 \%)$ and improvement in $14(50 \%)$, whereas 7 patients had stable disease (25\%), and $1(4 \%)$ deteriorated and died. At the end of follow-up, with a median of 32 months, 5 patients (18\%) had died, and 2 (40\%) were using infliximab at the time of death. Tapering or discontinuation of corticosteroids without a relapse was achieved in 19 of 28 patients (68\%). In patients with decreasing dosing or discontinuation of infliximab, a relapse occurred in 5 of 19 patients (26\%). Complications of infliximab were reported in 10 of 28 patients (36\%) and mainly consisted of infections in $8(29 \%)$.

\section{Conclusion}

Infliximab is an effective treatment in neurosarcoidosis leading to remission or improvement in $70 \%$. The mortality rate in infliximab-treated patients was substantial, indicating the severity of disease and treatment-associated complications.

\section{Classification of evidence}

This study provides Class IV evidence that in people with pathology-confirmed neurosarcoidosis, infliximab is beneficial. 


\section{Glossary}

AMC = Academic Medical Center; EMC = Erasmus MC; IQR = interquartile range; $\mathbf{m R S}=$ modified Rankin Scale; TNF$\boldsymbol{\alpha}=$ tumor necrosis factor alpha.

Sarcoidosis is a multisystem disorder and is characterized by the presence of granulomas that can affect every organ system. ${ }^{1}$ The prevalence of sarcoidosis in the population is estimated to be between 5 and 50 per 100.000, with the highest prevalence in Northern Europe. ${ }^{1}$ Approximately 5\% of patients with sarcoidosis have neurosarcoidosis, in which granulomas involve the nervous system. ${ }^{2}$ Neurosarcoidosis is a severe form of sarcoidosis in which one-third of patients remain stable, deteriorate, or die despite immunosuppressive treatment. ${ }^{2}$ No clinical trials have been performed in patients with neurosarcoidosis, and treatment choices are mainly based on evidence from non-neurologic sarcoidosis.

Treatment with infliximab, a tumor necrosis factor alpha (TNFa) blocker, has emerged as a promising option in the past years in patients with neurosarcoidosis refractory to first- or second-line therapy. ${ }^{3}$ TNF- $\alpha$ is a pivotal proinflammatory cytokine and plays a central role in the formation and maintenance of granulomas. ${ }^{4-6}$ Hence, therapeutic efficacy of TNF- $\alpha$ antagonists has recently been reported in refractory systemic and neurosarcoidosis. ${ }^{3,7-18}$ To substantiate this potential beneficial effect of TNF- $\alpha$ blockers, we analyzed the use of infliximab in patients with biopsy-proven neurosarcoidosis and evaluated the treatment response and safety in a large multicenter tertiary center cohort.

\section{Methods}

A retrospective study was performed with inclusion of all patients with biopsy-proven sarcoidosis and neurologic involvement who were treated with infliximab before June 1, 2017, at the Academic Medical Center (AMC) in Amsterdam and the Erasmus MC (EMC) in Rotterdam, 2 tertiary referral centers for (neuro)sarcoidosis in the Netherlands. Ethical approval is not required in the Netherlands for a retrospective study with anonymized patient data such as our study. Patients were identified by their treating physician, and data were collected in a database. The diagnosis of neurosarcoidosis was based on the Zajicek et al. criteria, later modified by Tavee and Stern. ${ }^{19,20}$ A positive histology for sarcoidosis was defined as the presence of histologic features consistent with sarcoidosis defined as noncaseating granulomas with epithelioid cells and macrophages. ${ }^{6}$

For all patients, a case record form was created containing baseline characteristics, disease course and immune-modulating medication used at baseline, clinical characteristics and results of ancillary investigations at baseline, infliximab treatment and treatment response, disease course and clinical outcome up to the last time of follow-up, and adverse events. Baseline was defined as the initiation of infliximab treatment. First-line therapy consisted of corticosteroid therapy, and second-line therapy consisted of methotrexate, azathioprine, mycophenolate mofetil, hydroxychloroquine, and cyclosporine. ${ }^{3}$ All patients were treated with an infliximab dosage of $5 \mathrm{mg} / \mathrm{kg}$. In the EMC, patients were treated at weeks 0,2 , and 6 during the induction phase, followed by an infusion once every 4-8 weeks based on the clinical features and seriousness by their treating physician. In the AMC, patients did not undergo an induction phase and immediately received infusions once every 4-8 weeks based on the clinical features and seriousness. All patients were initially treated with Remicade and were switched in 2016 to the biosimilar Remsima. All infections, infusion reactions, and laboratory abnormalities that occurred during the use of infliximab were reported. The response to treatment in each case was scored as remission or improvement on therapy (a favorable treatment response), stable disease (e.g., unchanged compared with clinical situation before treatment), and deterioration. The response rate was assessed about 3 months after the start of infliximab depending on time of follow-up. Clinical outcome was graded into functional disability at the last recorded hospital contact. The functional disability in each case was scored, using the modified Rankin Scale (mRS), as asymptomatic, complaints without functional disability, complaints with slight functional disability (e.g., able to look after own affairs, but unable to perform all previous activities), complaints with moderate disability (e.g., neurologic deficits mildly interfering in everyday life, such as inability to cycle due to motor dysfunction, but able to walk unassisted), complaints with moderate-to-severe functional disability (e.g., neurologic deficits interfering everyday life, resulting in failure to return to job or school, requirement of special equipment such as crutches or a wheelchair, or assistance with everyday activities), complaints with severe disability (e.g., requires constant nursing care and attention, bedridden, and/or incontinent), and death. An mRS score of asymptomatic or complaints without functional disability was considered a favorable outcome.

Statistical analysis was performed to compare differences between groups using the Fisher exact test for dichotomous variables and the Mann-Whitney $U$ test for ordinal and continuous variables. A $p$ value $<0.05$ was considered significant.

This study was designed to assess the efficacy and risks of treatment with infliximab (anti-TNF- $\alpha$ ) in pathology-confirmed neurosarcoidosis. This study provides Class IV evidence.

\section{Data availability}

Anonymized data not published in the article are available on request by any qualified investigator. 


\section{Results}

\section{Clinical characteristics}

A total of 28 patients were included, 11 in the AMC and 17 in the EMC. Baseline characteristics, clinical manifestations, and ancillary investigations at the start of infliximab are described in table 1 and were comparable in both centers. The median time of follow-up was 32 months (interquartile range [IQR] 17-54 months). The included patients had a mean age at baseline of 42 years (SD 10.3), and 16 (57\%) were male. Of these patients, 16 (57\%) were Caucasian, 6 (21\%) of African descent, and 6 (21\%) had other ethnic backgrounds. Neurologic involvement at the start of infliximab consisted of parenchymal involvement in 16 patients (59\%), pituitary/hypothalamic involvement in 15 (54\%), peripheral nerve involvement in 12 (43\%), chronic meningitis in $11(41 \%)$, cranial nerve palsy in $7(25 \%)$, hydrocephalus in $6(22 \%)$, spinal cord involvement in $5(18 \%)$, and muscle involvement in 1 patient (4\%). The main neurologic symptoms were paresis in 12 of 28 patients (43\%), sensory symptoms in 12 (43\%), impaired gait in 11 (39\%), and headache in 10 (35\%). Overall, 27 of 28 patients (96\%) had multiple symptoms. The majority of patients had systemic involvement including lymph node (72\%), intrapulmonary $(27 \%)$, and ophthalmologic (22\%) localizations of sarcoidosis. The median mRS score at baseline was 3 (range 0-5). According to the Zajicek et al. criteria, 2 patients were diagnosed with definite and 26 patients with probable neurosarcoidosis, all with pathology confirmation of noncaseating granulomas. Treatment used at the start of infliximab consisted of corticosteroids in 11 patients (39\%), prednisolone and methotrexate in $6(21 \%)$, prednisolone and azathioprine in $4(14 \%)$, methotrexate and prednisone with mycophenolate mofetil in 2 (7\%), and prednisone with hydroxychloroquine in 1 patient (4\%). Three patients were not receiving immunosuppressive medication at the start of infliximab, but had received this previously. Before the start of infliximab, all patients had been treated with corticosteroids, 14 (50\%) with methotrexate, 13 (46\%) with azathioprine, 5 (18\%) with mycophenolate mofetil, 2 (7\%) with cyclophosphamide, and 1 (4\%) with hydroxychloroquine or cyclosporine. Overall, 24 of 28 patients $(86 \%)$ had previously been treated with a second-line treatment (table 1). The reasons to start infliximab were a relapse when tapering corticosteroids despite second-line treatment in 16 of 28 patients (57\%), serious side effects of firstand/or second-line treatment in 8 (29\%), chronic progression despite first- and/or second-line treatment in $3(11 \%)$, and a relapse after tapering corticosteroids in 1 patient (4\%).

\section{Therapeutic outcome}

The starting dose of infliximab of $5 \mathrm{mg}$ per kilogram was given once every 4 weeks in 5 patients (18\%), once every 6 weeks in 12 patients (43\%), and once every 8 weeks in 11 patients (39\%). The median total number of infusions was 17 (range 5-50), and infliximab treatment had a median duration of 23 months (IQR 12-38 months). The initial treatment response consisted of remission in 6 patients (21\%), improvement in $14(50 \%)$, stable disease in 7 (25\%), and death in 1 patient (4\%) (table 2). Treatment responses were comparable in both centers. The sIL2R values returned to normal levels in 9 (64\%) and improved in 2 of 14 patients (14\%), although the change was not statistically significant (figure 1). MRI of the brain and/or spinal cord was repeated in 21 patients at follow-up, and radiologic abnormalities attributed to neurosarcoidosis decreased in $15(71 \%)$, remained stable in 4 patients (19\%), and increased in 1 patient (7\%). When looking at a favorable treatment response, we did not find an association of time between the diagnosis neurosarcoidosis and the start of infliximab $(p=0.165)$. Also, a favorable outcome of 0 or 1 on the $\mathrm{mRS}$ was not associated $(p=0.80)$. Furthermore, the use of second-line therapy at the start of infliximab was not associated with a favorable treatment response $(13 / 15$ [87\%] with secondline treatment vs $7 / 13[54 \%]$ without second-line treatment, $p=$ $0.10)$. The use of second-line therapy is not associated with a favorable outcome on the $\mathrm{mRS}(7 / 15$ [47\%] with second-line treatment vs $5 / 13[38 \%]$ without second-line treatment, $p=0.72$ ).

In patients with a favorable treatment response, the infliximab dosage was decreased in 2 of 20 patients (10\%) and was stopped in $11(55 \%)$, which led to a relapse in 4 of 13 patients (31\%). In patients with an unfavorable treatment response, infliximab was stopped in 4 of 8 patients (50\%) and led to a relapse in 1 of 4 patients (25\%). In patients in whom treatment regimen was not altered, a relapse occurred in 1 of 11 patients (9\%), which was attributed to the stop of methotrexate because of liver toxicity.

Overall, a relapse was not associated with the length of infliximab use before discontinuation $(p=0.31)$. In patients with a relapse after the treatment regimen was altered, infliximab was restarted, or dosage was increased in all, leading to a favorable treatment response in 4 patients and stable disease in 1 patient. Autoantibodies against infliximab were tested in 5 patients who experienced a relapse and were positive in 1 patient. This patient was switched to adalimumab, which led to improvement. At the last time of follow-up, 6 of 28 patients (21\%) were asymptomatic, $6(21 \%)$ had no significant disability, 5 (18\%) had slight disability, 3 (11\%) had moderate disability, 3 patient (11\%) had moderately severe disability, and $5(18 \%)$ died (figure 2). Overall, the change in the $\mathrm{mRS}$ was not significant $(p$ $=0.12$ ). Of the patients who died, cause of death was sepsis in 2 patients, and brain stem hemorrhage, malignancy, and an unknown cause of death each occurred in 1 patient. Of these patients, only the 2 patients with infectious complications used infliximab at the time of death, and both were on concomitant corticosteroid therapy. Complications attributed to infliximab treatment occurred in 10 of 28 patients (36\%) and consisted of infections in 8 patients (29\%) and elevated liver tests and an allergic reaction both in 1 patient (4\%). No adverse effects could be contributed to the switch to a biosimilar. Two patients reported an increase of pain and sensory symptoms without any signs of a relapse or disease activity.

\section{Discussion}

We report a favorable long-term outcome in patients with pathology-confirmed neurosarcoidosis treated with infliximab. However, we observe a relative high mortality at follow-up and a high occurrence of infectious complications. This further 
Table 1 Baseline characteristics and disease course at baseline

\begin{tabular}{|c|c|c|c|}
\hline Characteristic & n/N (\%) & Characteristic & n/N (\%) \\
\hline Age at baseline (IQR), $y^{a}$ & $42(33-49)$ & Zajicek criteria & \\
\hline Male sex & $16(57)$ & Definite neurosarcoidosis & $2 / 28(7)$ \\
\hline Ethnicity & & Probable neurosarcoidosis & $26 / 28(93)$ \\
\hline Caucasian & $16(57)$ & mRS score at baseline & $3(0-5)^{c}$ \\
\hline African descent & $6(21)$ & Asymptomatic & $1 / 28(4)$ \\
\hline Other ${ }^{b}$ & $6(21)$ & No significant disability & $4 / 28(14)$ \\
\hline Neurologic involvement & & Slight disability & $6 / 28(21)$ \\
\hline Parenchymal & $16 / 27(59)$ & Moderate disability & $6 / 28(21)$ \\
\hline Neuroendocrine & $15 / 27(56)$ & Moderate-severe disability & $5 / 28(18)$ \\
\hline Peripheral nerve & $11 / 27(41)$ & Severe disability & $6 / 28(21)$ \\
\hline Polyneuropathy & $8 / 11(73)$ & Ancillary investigations & \\
\hline Radiculopathy & $2 / 11(18)$ & Serum ACE $>70 \mathrm{U} / \mathrm{L}$ & $3 / 17(18)$ \\
\hline Plexopathy & $1 / 11(9)$ & Serum sIL2r $>3,000 \mathrm{U} / \mathrm{mL}$ & $11 / 15(73)$ \\
\hline Chronic aseptic meningitis & $11 / 27(41)$ & Serum CRP >10 mg/L & $7 / 21(33)$ \\
\hline Cranial nerve palsy & $7 / 27(26)$ & Serum ESR $>20 \mathrm{~mm} / \mathrm{h}$ & $8 / 19(42)$ \\
\hline Hydrocephalus & $6 / 27(22)$ & CSF leukocytes $>5 \times 10^{6}$ cells $/ \mathrm{L}$ & $6 / 6(100)$ \\
\hline Spinal cord & $5 / 27(19)$ & CSF protein $>0.6 \mathrm{~g} / \mathrm{L}$ & $6 / 6(100)$ \\
\hline Muscle & $1 / 27(4)$ & Chest $\mathrm{CT}$ suggestive & $3 / 4(75)$ \\
\hline Neurologic symptoms & & ${ }^{18} \mathrm{~F}$-FDG PET-CT suggestive & $1 / 6(16)$ \\
\hline Paresis & $12 / 28(43)$ & Brain MRI suggestive & $21 / 22(95)$ \\
\hline Sensory symptoms & $12 / 28(43)$ & Spinal cord MRI suggestive & $2 / 7(29)$ \\
\hline Impaired gait & $11 / 28(39)$ & Immunosuppressant use at baseline & \\
\hline Headache & $10 / 28(35)$ & Corticosteroids & $11 / 28(39)$ \\
\hline Cognitive/psychiatric & $8 / 28(29)$ & Corticosteroids + methotrexate & $6 / 28(21)$ \\
\hline Visual symptoms & $7 / 28(25)$ & Corticosteroids + azathioprine & $4 / 28(14)$ \\
\hline Impaired coordination & $5 / 28(18)$ & Methotrexate & $2 / 28(7)$ \\
\hline Speech impairment & $4 / 28(15)$ & Corticosteroids + hydroxychloroquine & $1 / 28(4)$ \\
\hline Facial palsy & $4 / 28(15)$ & Corticosteroids + MMF & $2 / 28(7)$ \\
\hline Vertigo & $3 / 28(11)$ & None & $3 / 28(11)$ \\
\hline Seizure & $2 / 28(7)$ & Prior immunosuppressant use & \\
\hline Hearing loss & $1 / 28(4)$ & Corticosteroids & $28 / 28(100)$ \\
\hline Multiple symptoms & $27 / 28(96)$ & Methotrexate & $14 / 28(50)$ \\
\hline Systemic involvement & & Azathioprine & $13 / 28(46)$ \\
\hline Lymph node & $18 / 25(72)$ & Mycophenolate mofetil & $5 / 28(18)$ \\
\hline Lungs & $7 / 26(27)$ & Cyclophosphamide & $2 / 28(7)$ \\
\hline Eye & $6 / 27(22)$ & Hydroxychloroquine & $1 / 28(4)$ \\
\hline ENT & $3 / 28(11)$ & Cyclosporine & $1 / 28(4)$ \\
\hline Skin & $2 / 27(7)$ & No. of prior immunosuppressants & \\
\hline
\end{tabular}


Table 1 Baseline characteristics and disease course at baseline (continued)

\begin{tabular}{llll}
\hline Characteristic & $\mathbf{n} / \mathbf{N}(\%)$ & Characteristic & $\mathbf{n} / \mathbf{N}(\%)$ \\
\hline Joints & $1 / 28(4)$ & One type & 4/28 (14) \\
\hline Endocrinologic & $5 / 28(18)$ & Two types & $16 / 28(57)$ \\
\hline & & Three types & $6 / 28(21)$ \\
\hline & & Five types & 2/28 (7) \\
\hline
\end{tabular}

Abbreviations: $\mathrm{ACE}=$ angiotensin-converting enzyme; $\mathrm{ESR}=$ erytrocyte sedimentation rate; $\mathrm{IQR}=$ interquartile range; $\mathrm{MMF}=$ mycophenolate $\mathrm{mofetil}$; $\mathrm{mRS}=$ modified Rankin Scale; sIL2r = soluble interleukin 2 receptor.

a Median (IQR).

${ }^{\mathrm{b}}$ Other ethnicities: 2 (7\%) North African, 2 (7\%) Hindustan, 1 (4\%) Asian, and 1 (4\%) Hispanic.

'Median (range).

establishes TNF- $\alpha$ antagonists as a suitable third-line agent in patients with insufficient response to first- and second-line treatment, but follow-up remains essential to taper when possible and evaluate for infectious complications.
In our cohort, remission or clinical improvement was achieved in $71 \%$ of patients, which is in line with 2 previously published studies. To date, the evidence for the use of infliximab in neurosarcoidosis consists of case reports and

Table 2 Treatment and outcome

\begin{tabular}{|c|c|c|c|}
\hline Characteristic & $\mathrm{n} / \mathrm{N}(\%)$ & Characteristic & n/N (\%) \\
\hline Months between sarcoidosis and IFX ${ }^{a}$ & $27(18-42)$ & Result of change/stop IFX & \\
\hline Months between neurosarcoidosis and IFX & $19(9-41)$ & None & $9 / 17(53)$ \\
\hline Months between IFX and last follow-up ${ }^{a}$ & $32(17-54)$ & Relapse & $5 / 17(29)$ \\
\hline Infliximab duration in $\mathrm{mo}^{\mathrm{a}}$ & $23(12-38)$ & Unknown & $3 / 17(18)$ \\
\hline Total number of infusions ${ }^{b}$ & $17(5-50)$ & 1st- or 2 nd-line treatment change & \\
\hline Treatment response & & Taper of 1st-line treatment & $10 / 23(43)$ \\
\hline Remission & $6 / 28(21)$ & Stop of 1st-line treatment & $13 / 23(57)$ \\
\hline Improvement & $14 / 28(50)$ & Stop of 2 nd-line treatment & $5 / 14(36)$ \\
\hline Stable disease & $7 / 28(25)$ & Complications of IFX treatment & $10 / 28(36)$ \\
\hline Deterioration & $1 / 28(4)$ & Infections $^{d}$ & $8 / 28(29)$ \\
\hline Change of neurologic imaging & & Elevated liver tests & $1 / 28(4)$ \\
\hline Improvement & $15 / 21(71)$ & Allergic reaction & $1 / 28(4)$ \\
\hline Stable & $4 / 21(19)$ & Modified Rankin Scale score & $2(0-6)$ \\
\hline Other abnormalities & $2 / 21(10)$ & Asymptomatic & $6 / 28(21)$ \\
\hline IFX dosage decrease or stop & $17 / 28(61)$ & No significant disability & $6 / 28(21)$ \\
\hline Good treatment response & $8 / 17(47)$ & Slight disability & $5 / 28(18)$ \\
\hline Insufficient treatment response & $1 / 17(6)$ & Moderate disability & $3 / 28(11)$ \\
\hline Major side effects & $4 / 17(24)$ & Moderate-severe disability & $3 / 28(11)$ \\
\hline Stable symptoms, no disease activity & $2 / 17(12)$ & Moderate disability & $0 / 28(0)$ \\
\hline Other ${ }^{c}$ & $2 / 17(12)$ & Death & $5 / 28(18)$ \\
\hline Autoantibodies & $1 / 5(20)$ & & \\
\hline
\end{tabular}

${ }^{a}$ Median (interquartile range).

${ }^{\mathrm{b}}$ Median (range).

c Other: 1 patient developed autoantibodies against infliximab, and 1 patient decided to stop.

${ }^{d}$ Infections consisted of pneumonia in 4 patients, urinary tract infection in combination with pneumonia in 1 patient, and urinary tract infection in 1 patient, all necessitating hospital admission. 

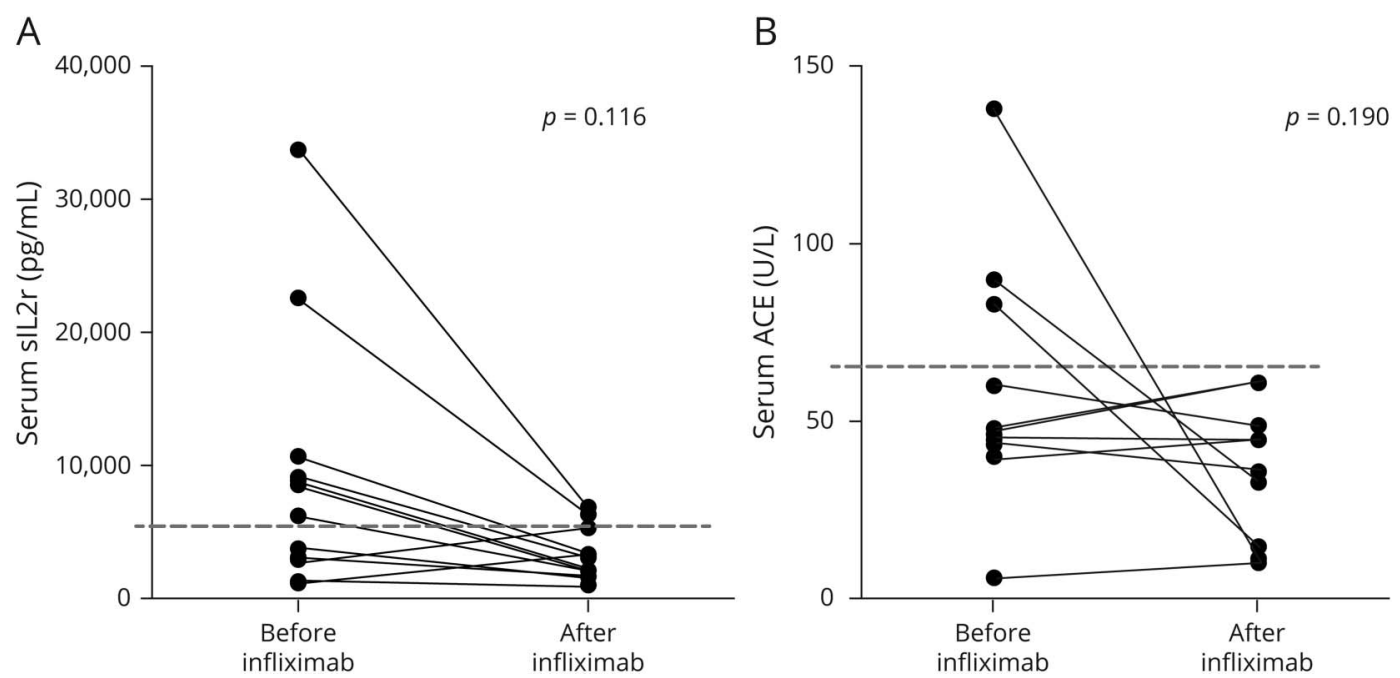

The dotted line indicates the upper limit of the normal value. $p$ Values were calculated using the Mann-Whitney $U$ test. (A) Serum sIL2r values before and after the start of infliximab. (B) Serum ACE values before and after the start of infliximab. ACE = angiotensin-converting enzyme; sIL2r = soluble interleukin 2 receptor

series and 2 retrospective multicenter cohort studies. ${ }^{10-18} \mathrm{~A}$ summary of published articles describing 4 or more patients treated with infliximab can be found in table e-1, links.lww. com/NXI/A289. The 2 retrospective multicenter cohort studies describe 18 and 66 patients with probable or definite neurosarcoidosis, respectively, describing improvement or remission in $89 \%$ and $77 \%$ of patients. ${ }^{13,14}$ Of interest, despite a shorter median time of follow-up of 20 and 18 months, respectively, these articles describe higher relapse rates of $50 \%$ and $56 \%$ compared with the overall relapse rate of $21 \%$ in our cohort. A correlation between the duration of neurosarcoidosis and a favorable treatment response was previously described, but this finding could not be reproduced in our cohort. ${ }^{14}$ However, given the severity of the neurologic

Figure 2 Modified Rankin Scale score change of follow-up compared with baseline

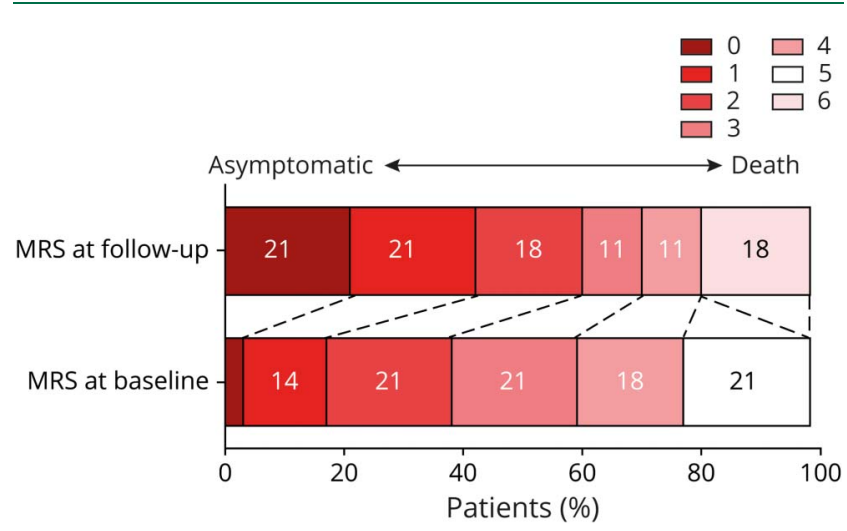

0: asymptomatic, 1: complaints without functional disability, 2: complaints with slight functional disability, 3: complaints with moderate disability, 4: complaints with moderate-to-severe functional disability, 5: complaints with severe disability, and 6: death. mRS = modified Rankin Scale. manifestations, it seems reasonable to start infliximab when first-line treatment fails and a quick treatment response is required or when second-line treatment fails.

Importantly, we report a mortality rate of $18 \%$, which is higher compared with previously published meta-analysis of patients with neurosarcoidosis (5\%) and the aforementioned retrospective studies on TNF- $\alpha$ antagonists in neurosarcoidosis ( $5 \%$ and $0 \%$, respectively). ${ }^{2,13,14}$ In a large retrospective study evaluating prognostic factors in neurosarcoidosis with a median follow-up of 8 years, 21 of 234 patients (9\%) died, 3 of which due to sepsis. ${ }^{21}$ Our high mortality rate may be explained by the severely affected population, which is selected for infliximab treatment. Of the patients who died, 2 of 5 patients were using infliximab infusions combined with firstand second-line immunosuppressants at the time of death, and both died due to infectious complications due to their severely immunocompromised state. The occurrence of infections is an important adverse effect, occurring in $29 \%$ of the patients. The infection rate is comparable to other studies describing infliximab use in neurosarcoidosis, which varied between 10 and 39\%, although in these studies, none of the patients died due to infectious complications. ${ }^{13,14}$ The risk of infectious complications is considered to be higher when patients are treated in combination with corticosteroids or other immunosuppressive drugs. ${ }^{22,23}$ Of interest, as shown by figure 2, the high mortality rate is flanked by an increase of favorable outcome as measured by the $\mathrm{mRS}$ at baseline compared with follow-up. The combined data suggest that infliximab should be reserved to patients with severe disease and that tapering corticosteroids remains essential when signs of disease activity have diminished. In our cohort, starting infliximab was followed by tapering of concomitant first-line treatment in $43 \%$ of patients and eventually complete 
discontinuation of corticosteroids in $57 \%$ of patients. This is in line with another study describing discontinuation of steroids after the start of infliximab in $40 \%$ of the patients and maintenance of prednisone on $5 \mathrm{mg}$ per day or less in $27 \%$ of the patients. ${ }^{14}$ Prompt tapering of steroids is essential to prevent adverse effects and reduce the risk of infections in severely immunocompromised patients. ${ }^{24}$ Furthermore, combination therapy with another steroid-sparing agent may be associated with a favorable treatment response to infliximab. ${ }^{14}$ This could not be reproduced in our cohort, but considering the small sample size, a possible association might be missed.

Currently, no international guidelines exist on how to proceed after a favorable treatment response following infliximab treatment. In patients in whom infliximab treatment was stopped or dosage was decreased in our cohort, $26 \%$ had a relapse of disease activity compared with $56 \%$ in an earlier published study. ${ }^{14}$ Relapse can occur after long-term infliximab treatment in patients with clinical and radiologic remission. ${ }^{14}$ It remains unknown at what moment in the disease course infliximab should be tapered and stopped. In case of a relapse, dosage can be increased, and/or intervals between infusions can be shortened quickly. In our cohort, when patients were reintroduced to infliximab, they were likely to show a good treatment response again, similar to what have been reported in inflammatory bowel disease. ${ }^{25}$ Although rare, when a relapse occurs during infliximab treatment or when reintroduction fails, it is important that this can be due to autoantibody formation. ${ }^{26,27}$ In a study assessing the safety and efficacy of TNF- $\alpha$ antagonists in refractory sarcoidosis, 3 of 132 (2\%) developed autoantibodies. ${ }^{28}$ In other inflammatory disorders including Crohn disease, concomitant methotrexate is advised as this has been shown to be efficient in reducing immunogenicity, although evidence in patients with sarcoidosis is lacking. ${ }^{29}$

Our study has several limitations. First, both the retrospective and multicenter approach of our study resulted in heterogeneous assessment of disease activity, treatment strategies, and outcome, as well as missing data in some patients. Furthermore, treatment strategies differed between the 2 centers. In the EMC, an induction phase was used when they started patients on infliximab, whereas the AMC initiates treatment once every 4-8 weeks without an initial induction phase. Despite these differences, baseline characteristics and treatment response did not differ between the 2 centers. However, sIL2R measurements were only performed in the EMC cohort. These limitations are inherent to the study design. In addition, a majority of patients were treated with first- and/or second-line therapy possibly contributing to treatment responses and the occurrence of side effects. Last, we included only patients treated in our tertiary referral centers, introducing a selection bias. We feel that patients with neurosarcoidosis treated with infliximab must be treated at specialized centers, which is the norm in the Netherlands. Furthermore, both tertiary referral centers are specialized centers in neuromuscular diseases, which may add to the relative high proportions of patients with peripheral nerve involvement. However, in none of the patients, peripheral nerve involvement was the primary indication for infliximab start.

In conclusion, anti-TNF- $\alpha$ antagonists can be effective in neurosarcoidosis; however, physicians should be aware of possible side effects as seen in about a third of patients in our cohort, with a risk of serious infectious complications. Future randomized controlled trials and prospective cohort studies to assess the safety of infliximab are warranted and should shed light over whether mono- or combination therapy is preferred and when and how to taper and stop infliximab during follow-up.

\section{Study funding}

M.C. Brouwer is supported by a grant from the Netherlands Organization for Health Research and Development (ZonMw; NWO-Vidi grant 2017 [917.17.308]). D. van de Beek is supported by grants from the Netherlands Organization for Health Research and Development (ZonMw; NWO-Vici grant 2019 [918.19.627]), the European Research Council (ERC Starting Grant 281156), and an Innovation grant by the board of directors of the Amsterdam UMC, Amsterdam, the Netherlands. No potential conflict of interest relevant for this article exists.

\section{Disclosure}

The authors report no disclosures. Go to Neurology.org/NN for full disclosures.

\section{Publication history}

Received by Neurology: Neuroimmunology \& Neuroinflammation March 30, 2020. Accepted in final form June 16, 2020.

Appendix Authors

\begin{tabular}{|c|c|c|}
\hline Name & Location & Contribution \\
\hline Daan Fritz, MD & $\begin{array}{l}\text { Amsterdam UMC, } \\
\text { Amsterdam, The } \\
\text { Netherlands }\end{array}$ & $\begin{array}{l}\text { Substantial contribution to } \\
\text { conception and design, } \\
\text { acquisition of data, analysis } \\
\text { and interpretation of data, } \\
\text { drafted the manuscript, and } \\
\text { final approval of the version } \\
\text { to be published }\end{array}$ \\
\hline $\begin{array}{l}\text { Wilhelmina } \\
\text { M.C. } \\
\text { Timmermans, } \\
\text { MD }\end{array}$ & $\begin{array}{l}\text { Erasmus MC, } \\
\text { Rotterdam, The } \\
\text { Netherlands }\end{array}$ & $\begin{array}{l}\text { Substantial contribution to } \\
\text { conception and design, } \\
\text { acquisition of data, analysis } \\
\text { and interpretation of data, } \\
\text { drafted the manuscript, and } \\
\text { final approval of the version } \\
\text { to be published }\end{array}$ \\
\hline $\begin{array}{l}\text { Jan A.M. van } \\
\text { Laar, MD, PhD }\end{array}$ & $\begin{array}{l}\text { Erasmus MC, } \\
\text { Rotterdam, The } \\
\text { Netherlands }\end{array}$ & $\begin{array}{l}\text { Substantial contribution to } \\
\text { conception and design, } \\
\text { acquisition of data, analysis } \\
\text { and interpretation of data, } \\
\text { revised the manuscript for } \\
\text { important intellectual } \\
\text { content, and final approval of } \\
\text { the version to be published }\end{array}$ \\
\hline $\begin{array}{l}\text { Martin van } \\
\text { Hagen, MD, } \\
\text { PhD }\end{array}$ & $\begin{array}{l}\text { Erasmus MC, } \\
\text { Rotterdam, The } \\
\text { Netherlands }\end{array}$ & $\begin{array}{l}\text { Interpreted the data, revised } \\
\text { the manuscript, and final } \\
\text { approval of the version to be } \\
\text { published }\end{array}$ \\
\hline
\end{tabular}


Appendix (continued)

\begin{tabular}{|c|c|c|}
\hline Name & Location & Contribution \\
\hline $\begin{array}{l}\text { Theodora A.M. } \\
\text { Siepman, MD }\end{array}$ & $\begin{array}{l}\text { Erasmus MC, } \\
\text { Rotterdam, The } \\
\text { Netherlands }\end{array}$ & $\begin{array}{l}\text { Interpreted the data, revised } \\
\text { the manuscript, and final } \\
\text { approval of the version to be } \\
\text { published }\end{array}$ \\
\hline $\begin{array}{l}\text { Diederik van de } \\
\text { Beek, MD, PhD }\end{array}$ & $\begin{array}{l}\text { Amsterdam UMC, } \\
\text { Amsterdam, The } \\
\text { Netherlands }\end{array}$ & $\begin{array}{l}\text { Substantial contribution to } \\
\text { conception and design, } \\
\text { acquisition of data, analysis } \\
\text { and interpretation of data, } \\
\text { revised the manuscript for } \\
\text { important intellectual } \\
\text { content, and final approval of } \\
\text { the version to be published }\end{array}$ \\
\hline $\begin{array}{l}\text { Matthijs C. } \\
\text { Brouwer, MD, } \\
\text { PhD }\end{array}$ & $\begin{array}{l}\text { Amsterdam UMC, } \\
\text { Amsterdam, The } \\
\text { Netherlands }\end{array}$ & $\begin{array}{l}\text { Substantial contribution to } \\
\text { conception and design, } \\
\text { acquisition of data, analysis } \\
\text { and interpretation of data, } \\
\text { revised the manuscript for } \\
\text { important intellectual } \\
\text { content, and final approval of } \\
\text { the version to be published }\end{array}$ \\
\hline
\end{tabular}

\section{References}

1. Valeyre D, Prasse A, Nunes H, Uzunhan Y, Brillet PY, Muller-Quernheim J. Sarcoidosis. Lancet 2014;383:1155-1167.

2. Fritz D, van de Beek D, Brouwer MC. Clinical features, treatment and outcome in neurosarcoidosis: systematic review and meta-analysis. BMC Neurol 2016;16:220.

3. Fritz D, Voortman M, van de Beek D, Drent M, Brouwer MC. Many faces of neurosarcoidosis: from chronic meningitis to myelopathy. Curr Opin Pulm Med 2017;23:439-446.

4. Baughman RP, Iannuzzi M. Tumour necrosis factor in sarcoidosis and its potential for targeted therapy. BioDrugs 2003;17:425-431.

5. Baughman RP, Strohofer SA, Buchsbaum J, Lower EE. Release of tumor necrosis factor by alveolar macrophages of patients with sarcoidosis. J Lab Clin Med 1990;115:36-42.

6. Timmermans WM, van Laar JA, van Hagen MP, van Zelm MC. Immunopathogenesis of granulomas in chronic autoinflammatory diseases. Clin Transl Immunol 2016;5:e118.

7. Baughman RP, Drent M, Kavuru M, et al. Infliximab therapy in patients with chronic sarcoidosis and pulmonary involvement. Am J Respir Crit Care Med 2006;174:795-802.

8. Rossman MD, Newman LS, Baughman RP, et al. A double-blinded, randomized, placebo-controlled trial of infliximab in subjects with active pulmonary sarcoidosis. Sarcoidosis Vasc Diffuse Lung Dis 2006;23:201-208.

9. Adler BL, Wang CJ, Bui TL, Schilperoort HM, Armstrong AW. Anti-tumor necrosis factor agents in sarcoidosis: a systematic review of efficacy and safety. Semin Arthritis Rheum 2019;48:1093-1104.
10. Hostettler KE, Studler U, Tamm M, Brutsche MH. Long-term treatment with infliximab in patients with sarcoidosis. Respiration 2012;83:218-224.

11. Santos E, Shaunak S, Renowden S, Scolding NJ. Treatment of refractory neurosarcoidosis with Infliximab. J Neurol Neurosurg Psychiatry 2010;81:241-246.

12. Riancho-Zarrabeitia L, Delgado-Alvarado M, Riancho J, et al. Anti-TNF-alpha therapy in the management of severe neurosarcoidosis: a report of five cases from a single centre and literature review. Clin Exp Rheumatol 2014;32:275-284.

13. Cohen Aubart F, Bouvry D, Galanaud D, et al. Long-term outcomes of refractory neurosarcoidosis treated with infliximab. J Neurol 2017;264:891-897.

14. Gelfand JM, Bradshaw MJ, Stern BJ, et al. Infliximab for the treatment of CNS sarcoidosis: a multi-institutional series. Neurology 2017;89:2092-2100.

15. Sodhi M, Pearson K, White ES, Culver DA. Infliximab therapy rescues cyclophosphamide failure in severe central nervous system sarcoidosis. Respir Med 2009;103:268-273.

16. Panselinas E, Rodgers JK, Judson MA. Clinical outcomes in sarcoidosis after cessation of infliximab treatment. Respirology 2009;14:522-528.

17. Moravan M, Segal BM. Treatment of CNS sarcoidosis with infliximab and mycophenolate mofetil. Neurology 2009;72:337-340.

18. Russell E, Luk F, Manocha S, Ho T, O'Connor C, Hussain H. Long term follow-up of infliximab efficacy in pulmonary and extra-pulmonary sarcoidosis refractory to conventional therapy. Semin Arthritis Rheum 2013;43:119-124.

19. Tavee JO, Stern BJ. Neurosarcoidosis. Continuum (Minneap Minn) 2014;20 545-559.

20. Zajicek JP, Scolding NJ, Foster O, et al. Central nervous system sarcoidosisdiagnosis and management. QJM 1999;92:103-117.

21. Joubert B, Chapelon-Abric C, Biard L, et al. Association of prognostic factors and immunosuppressive treatment with long-term outcomes in neurosarcoidosis. JAMA Neurol 2017;74:1336-1344

22. Garcia-Vidal C, Rodriguez-Fernandez S, Teijon S, et al. Risk factors for opportunistic infections in infliximab-treated patients: the importance of screening in prevention. Eur J Clin Microbiol Infect Dis 2009;28:331-337.

23. Deepak P, Stobaugh DJ, Ehrenpreis ED. Infectious complications of TNF-alpha inhibitor monotherapy versus combination therapy with immunomodulators in in flammatory bowel disease: analysis of the Food and Drug Administration Adverse Event Reporting System. J Gastrointestin Liver Dis 2013;22:269-276.

24. Rizzato G, Riboldi A, Imbimbo B, Torresin A, Milani S. The long-term efficacy and safety of two different corticosteroids in chronic sarcoidosis. Respir Med 1997;91: 449-460.

25. Casanova MJ, Chaparro M, Garcia-Sanchez V, et al. Evolution after anti-TNF discontinuation in patients with inflammatory bowel disease: a multicenter long-term follow-up study. Am J Gastroenterol 2017;112:120-131.

26. Baert F, Noman M, Vermeire S, et al. Influence of immunogenicity on the long-term efficacy of infliximab in Crohn's disease. N Engl J Med 2003;348:601-608.

27. Ainsworth MA, Bendtzen K, Brynskov J. Tumor necrosis factor-alpha binding capacity and anti-infliximab antibodies measured by fluid-phase radioimmunoassays as predictors of clinical efficacy of infliximab in Crohn's disease. Am J Gastroenterol 2008;103:944-948.

28. Jamilloux Y, Cohen-Aubart F, Chapelon-Abric C, et al. Efficacy and safety of tumor necrosis factor antagonists in refractory sarcoidosis: a multicenter study of $132 \mathrm{pa}-$ tients. Semin Arthritis Rheum 2017;47:288-294.

29. Garces S, Demengeot J, Benito-Garcia E. The immunogenicity of anti-TNF therapy in immune-mediated inflammatory diseases: a systematic review of the literature with a meta-analysis. Ann Rheum Dis 2013;72:1947-1955. 


\section{Neurology \\ Neuroimmunology \& Neuroinflammation}

Infliximab treatment in pathology-confirmed neurosarcoidosis

Daan Fritz, Wilhelmina M.C. Timmermans, Jan A.M. van Laar, et al.

Neurol Neuroimmunol Neuroinflamm 2020;7;

DOI 10.1212/NXI.0000000000000847

This information is current as of July 27, 2020

\section{Updated Information \& Services}

References

Citations

Subspecialty Collections

Permissions \& Licensing

Reprints including high resolution figures, can be found at:

http://nn.neurology.org/content/7/5/e847.full.html

This article cites 29 articles, 2 of which you can access for free at: http://nn.neurology.org/content/7/5/e847.full.html\#\#ref-list-1

This article has been cited by 2 HighWire-hosted articles: http://nn.neurology.org/content/7/5/e847.full.html\#\#otherarticles

This article, along with others on similar topics, appears in the following collection(s):

All Immunology

http://nn.neurology.org//cgi/collection/all_immunology

Class IV

http://nn.neurology.org//cgi/collection/class_iv

Cohort studies

http://nn.neurology.org//cgi/collection/cohort_studies

Information about reproducing this article in parts (figures,tables) or in its entirety can be found online at:

http://nn.neurology.org/misc/about.xhtml\#permissions

Information about ordering reprints can be found online: http://nn.neurology.org/misc/addir.xhtml\#reprintsus

Neurol Neuroimmunol Neuroinflamm is an official journal of the American Academy of Neurology.

Published since April 2014, it is an open-access, online-only, continuous publication journal. Copyright

Copyright $\odot 2020$ The Author(s). Published by Wolters Kluwer Health, Inc. on behalf of the American

Academy of Neurology.. All rights reserved. Online ISSN: 2332-7812.

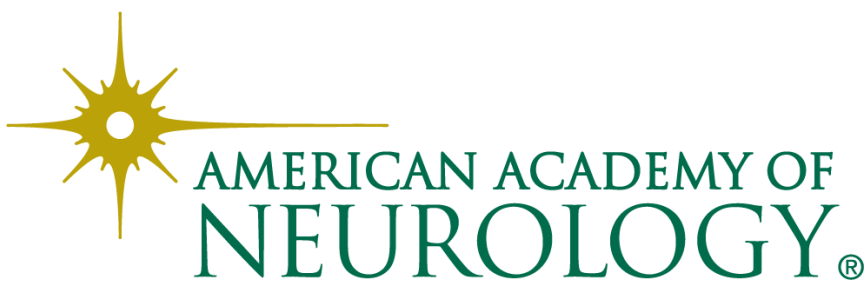

